\title{
An Analysis of Code Switching in Leila S. Chudori's For Nadira
}

\author{
Lusiana Kartika Candra', Laila Ulsi Qodriani ${ }^{2}$
}

lcandra69@gmail.com ${ }^{1}$, ani@teknokrat.ac.id ${ }^{2}$

Universitas Teknokrat Indonesia ${ }^{1,2}$

\begin{abstract}
This research focused on analysis of types and reasons of using code switching by the characters in For Nadira novel. The writers applied Hoffman theory which functioned to categorize the types of code switching, and Holmes which functioned to explain the reason why the speakers do code switching. Besides, this research also adopted qualitative method, since the analysis dealt with words instead of numbers. The results of the analysis showed that there are four types of code switching occurred in For Nadira novel. Those are intra-sentential switches, intersentential switches, establishing continuity switches, and emblematic switching. Then, there are seven reasons influenced the characters in For Nadira novel switch their language. Those are to assert power, pride and status, to declare the solidarity, to express ethnic identity, to express self-emotion, to being more competence, to being more informative and to convey the speaker's attitude to the listener.
\end{abstract}

Key Words: Code switching, For Nadira, reason, sosiolinguistics, types

\section{Introduction}

Living in the country which consists of different cultures and languages, people intentionally learn, adapt and use different languages in order to be able to communicate with other people from different cultures. For example, Indonesia has more than 100 regional languages, some of them are Javanese, Sundanese, Maduranese, Lampungnese, etc. As the result, most of Indonesian people can speak more than one language. They can speak not only Bahasa Indonesia but also can speak either ethnic or regional languages. So, if they speak with other people from different ethnic, they will change and choose language which is understood by the listeners fitting to the situation and their needs.

According to Wardaugh (2006) the phenomenon of people having more than one code (language) is called bilingualism or multilingualism. Since people are involved in bilingual or multilingual communication, it is possible for them to choose the language and switch that language in their speech. This phenomenon is known as code switching. Poplack and Sankoff (1984) states that code switching is simply the alternate use of the two languages in discourse. Meanwhile, Wardhaugh says that selecting a particular code is usually required by people whenever they choose to speak and they may also decide to switch from one code to another even sometimes in very short utterances and so create a new code in a process is known code switching. As a result, people in some communities choose different languages regarding the situations that demand them to speak.

The phenomenon of code switching not only happened in real life of the society around the world but also in literary work especially in the novel. One of them is For Nadira novel by Leila S. Chudori. This novel tells the story of the reflection of people's life nowadays, mainly the parts of women prepare to survive for her life. This novel was originally published as 9 Dari Nadira in 2009. Then, 9 Dari Nadira novel was expanded to the English version as For Nadira in 2015 produced by KPG (Keperpustakaan Populer Gramedia) in Jakarta, Indonesia. This research is conducted to find out the phenomenon of code switching more deeply in For Nadira novel. The character in For Nadira novel often switches some languages in their dialogues such as English to Indonesian, English to Ducth and English to Javanese. Moreover, the character in this novel also switches the language in the different cases. Therefore, the writer gets interested in finding and analyzing the types and the reason of the use of code switching used in the utterances of the characters in For Nadira novel.

\section{Theory}

\section{Types of Code Switching}

According to Bokamba in Ayeomoni (2006: 91) "code-switching is the mixing of words, phrases and sentence from two distinct grammatical (sub) systems across sentence boundaries within the same speech event." 
Using more than two languages is a normal in many parts of the world. It is in line with Wardaugh's opinion (1998:100) stating that the ability to shift from one language to another is accepted as quite normal. He further adds,

Most speakers command several varieties of any language they speak, and bilingualism, even multilingualism, is the norm for many people throughout the world rather than unbilingualism. People are usually required to select a particular code whenever they choose to speak, and they may also decide to switch from one code to another or mix codes. Even within sometimes very short utterance and thereby create a new code in a process known as code switching.

Similarly, Holmes (1992) says that features of bilingual speech such interference, code mixing, and code switching are normal phenomenan because bilingual often find it is easier to discuss a particular topic in one language rather than another. Hoffman (1991) adds that code switching is potentially the most creative aspect of bilingual speech. This situation may be the basic reason why people do code switching in their conversation.

Hoffman (1991) argue that the most general description of code switching is that it involves the alternate use of two languages or linguistics varieties within the same utterance or during the same conversation. In similar way, Romaine (2000) says that code switching is utterances draw to differing extents on items which come from than one languages and which are combined in different ways. In addition, Gall as reported in Wardaugh (1998) explains that code switching is a conversational strategy used to establish, cross or destroy group boundaries, to create, evoke or change interpersonal relations with their rights and obligations.

Wardaugh (2006) stated code switching is a conversation between speaker's turns or within a single speaker's turn. In the latter case it can occur between sentences or within a single sentence. Code switching can arise from individual choice or be used as a major identity marker for a group of speakers who must deal with more than one language in their common pursuits. Code switching occurs when a speaker requires a particular code, in order to switch one code to another and even create a new code in process (Wardaugh, 1986). Code switching is the changes over sentences (Hoffman, 1991). Code switching can occur during the same conversation.

Hoffman (1991) explains that code switching can occur quite frequently in an informal conversation among people who are familiar and have a shared educational, ethnic, and socio-economic background. It is avoided in a formal speech situation among people especially to those who have little in common factors in terms of social status, language loyalty, and formality. Hoffman (1991) states that there are four types of code switching, which are:

\section{a. Intra-Sentential Switches}

It contains the switch that occurs within a clause or sentence boundary, where each clause or sentence is in one or other language.

For example: when a Spanish - English bilingual says:

I started going like this. Y luego decia (and then he said). Look at the smoke coming out of my fingers (Hoffman, 1991: 220).

\section{b. Inter-Sentential Switches}

It contains the switch that occurs between a clause or sentence boundary where each clause or sentence is in one or other language.

For example: as when an adult Spanish-English bilingual says:

"Tenia zapatos blancos, un poco, they were off-white, you know." (Hoffman, 1991: 112).

\section{c. Establishing Continuity Switches}

This kind of code switching occurs to continue the utterance of the previous speaker, for example when one English speaker speaks in Spain, and then the other speaker tries to respond in Spain as well.

\section{d. Emblematic Switching}

In this kind of code switching, tags, exclamation and certain set of phrases in one language are inserted into an utterance otherwise in another.

For example: as when a Panjabi/English says:

"It's a nice day, hana?" (hai n? isn't it). Another example is when an adult Spanish American English says: “... Oh! Ay! It was embarrassing! It was very nice, though, but I was embarrassed!” (Hoffman, 1991: 112). 


\section{The Reasons for Code Switching}

Code switching is borrowing of the words from another language to express a concept or describe an object for which there is no obvious word available in the language by using. He adds that there are some causes of people to use code switching (Holmes, 1992). They are:

\section{a. Asserting Power, Pride and Status} authority.

People switch or mix two languages because code switching will increase the speaker's status, power and

\section{b. Declaring Solidarity} listeners.

Another reason why people use code switching is to express solidarity with particular social group or

\section{c. Expressing Ethnic Identity}

Language is one of the most important forms of human symbolic behavior and has become an identity of a social group. Alexander in Malesevic (2004: 49) define ethnicity as the real or perceived primordial qualities that accrue to a group by virtue of shared race, religion, or national origin, including in the latter category linguistic and other cultural attributes associated with a common territorial ancestry.

\section{d. Expressing Self Emotion}

In this case, a speaker can switch his or her code (language) in order to express self-emotion, such as angry, sad, or happy.

\section{e. Being More Competence}

Sometimes, speakers are unable to find the appropriate word in the language that is being used. Therefore, they switch or mix the language to another one (lack of vocabulary).

\section{f. Being More Informative (message oriented)}

People may select a particular variety of code to make the conversation easier to discuss a particular topic, regardless of where they are speaking (Holmes, 1992: 29). In addition, according to Hudson (2001: 131) speakers in every language can use language to locate themselves in relation to the people they are talking to and also in relation to people they are talking about. In some languages the central parts of the grammatical system are dedicated to this important social function, so it is important to bear these languages in mind as a corrective to the idea that the sole purpose of language is to convey messages efficiently.

\section{g. Conveying the Speaker's Attitude to the Listener.}

The speaker usually used code switching to convey their attitude to make the listener able to involve in the conversation.

\section{Findings and Discussion}

\section{Intra Sentential Switches}

According to Hoffman (1991:112-113) intra sentential switches is the switch occuring within a clause or sentence boundary, where each clause or sentence is in one or other language.

[.....] Our first meeting, like the ones that followed, did not go smoothly. Bram's father sat on the front terrace of their house in Gang Bluntas, Salemba, bagian dari Jakarta yang cuaca nya selalu panas. I could hear the student demonstrating just a few hundred meters away, going on and on (Leila, 2015: 20).

In the narration above shows that the speaker switches the language from English to Indonesian within a sentence and back again to English. The utterance Gang Bluntas, Salemba, bagian dari Jakarta yang cuaca nya selalu panas belongs to intra sentential switching because it occurs switching in phrases within a sentence. This switch occurs when narrator explain the place which is house of Bram's father that is friend of Nadira's father. The phrases "Gang Bluntas, Salemba, bagian dari Jakarta yang cuaca nya selalu panas" showed that she want to convey her messages efficiently with talking particular topic which is Gang Bluntas in Jakarta. Gang Bluntas is the place of Bram's father house in Salemba which is one of the parts of Jakarta. She wants to show and explain clearly 
and specifically of that place. So, the reason of the speaker switches the language because the speaker wants to be more informative when she explains her messages to the readers.

\section{Inter Sentential Switches}

According to Hoffman (1991:112-113) inter sentential switches contain switch occurs between a clause or sentence boundary, where each clause or sentence is in one or other language.
Mr. X was smiling slowly. Nadira was in his grasp now. How sweet it was. He restrained himself from touching her fingers, afraid she would snap out of it.
Nadira : Saya tidak pernah mengerti, mengapa ibu memutuskan untuk meninggal.
Mr. X : Your mother must've been bearing a very heavy burden... if not, she would never have decided to leave her three children that she loved so much... why do you think that she decided to go?
Nadira $\quad$ : I...I never understood why Ibu wanted chrysanthemums with her at her final resting place (Leila, 2015: 106).

The utterance above shows that Nadira switches her language from English to Indonesia between sentences in the conversation. The utterances "Saya tidak pernah mengerti, mengapa ibu memutuskan untuk meninggal" belongs to inter sentential switching because the change occurs between sentences boundary. The switching happened with no change situation. It switch because the speaker wonted to show her feeling about her mother who committed suicide. This switch occurs when Nadira talk with Mr. X about her mother passed away. The utterance "Saya tidak pernah mengerti, mengapa ibu memutuskan untuk meninggal" means that she expresses her selfemotion which is sadness and disappointed with her mother. From that utterance showed that she didn't willing her mother passed away eventually without any last words to say. Actually, she has many questions to ask but she was passed away before Nadira asking to her. So, the reason of the speaker switches the language because the speaker wants to express and show her emotion to the readers that she is sad and disappointed.

\section{Establishing Continuity Switches}

According to Hoffman (1991:112-113) this kind of code switching occurs to continue the utterance of the previous speaker.

Nadira, the reporter who had join Tera magazine just the week before, leapt up. She knew that Novena was a more senior reporter than she was.

Novena : "Oh, sit down, please. I'm Vena... Novena..." Novena extended her hand.

Nadira : "Saya Nadira, mbak. Please to meet you"

Novena : "Tidak perlu memanggilku mbak. We're about the same age, Dira." (Leila, 2015: 193).

From the utterances above clearly shows that Nadira and Novena switches their language into Indonesia. The utterances above belong to establishing continuity switches because when Nadira introduce herself to Novena, she uses Bahasa Indonesia and Novena tries to responds in Indonesia too. This switch occurs when Nadira introduce herself to Novena. The uses of code switching "Saya Nadira, mbak" means that the speaker wants to convey and show her the politeness attitude to Ms. Novena whose is more senior than her. It is very common in Indonesia uses the word "Mbak" to call someone who have not yet know before. Because Nadira meets with Novena in the first time, she calls her "Mbak". The uses of code switching "Saya Nadira, mbak" because Nadira respects Ms. Novena as her senior. Then, Novena replies her with used code switching "Tidak perlu memanggilku mbak" in order to responds Nadira because she respects her junior. So, the reason of the speaker switches the language because the speaker wants to convey the speaker's politeness attitude to the listener.

\section{Emblematic Switching}

According to Hoffman (1991:112-113) this kind of code switching, tags, exclamation and certain set phrases in one language are inserted into an utterance otherwise in another.

Novena : "I thought... I just thought... after the insidence of Nadira's mother committing suicide last month, people need to understand ..." 
Tara : "Tidak masuk akal..!!!” Tara and Novena were both startled with the way Tara barked. "Novena" Tara stood and grabbed Novena by the arm as she was moving away. "Sit, please sit down." (Leila, 2015: 198).

In that utterances shows that Tara switches his language from English to Indonesian "Tidak masuk akal..!!!" within a sentence and back again to English. The utterance above belongs to emblematic switching, because there was exclamation inserted into an utterance otherwise in another sentence. This switch occurs when Tara talks with Novena about his opinion that he didn't agree with Novena and he didn't like Novena's act because Novena seems like to laid down Nadira. The utterance "Tidak masuk akal..!!!" means that he expresses his self emotion which is angry and disagree with Novena's opinion. From that utterance showed that he didn't agree with Novena's opinion about suicide because it will hurt Nadira whose her mother committed suicide, as the result, Tara feels angry. The utterance "Tidak masuk akal..!!!" is represent his self-emotion which is angry. So, the reason of the speaker switches the language because the speaker wants to express and show his emotion that he is angry.

\section{Conclusion}

After analyzing this novel in previous chapter and relating it to the theory and approach of this research, the writer found 67 data. In the first discussion, all the types of code switching appeared in the conversation as shown in table below.

Table 5.1. Types of Code Switching

\begin{tabular}{|l|l|l|}
\hline $\begin{array}{l}\text { Types of Code Switching } \\
\text { in For Nadira }\end{array}$ & Frequency & Percentage \\
\hline Intra Sentential Switches & 8 & $12 \%$ \\
\hline Inter Sentential Switches & 45 & $67 \%$ \\
\hline Establishing Continuity Switches & 4 & $6 \%$ \\
\hline Emblematic Switching & 10 & $15 \%$ \\
\hline Total & $\mathbf{6 7}$ & $\mathbf{1 0 0} \%$ \\
\hline
\end{tabular}

The second discussion mainly is about the reasons of using code switching in For Nadira novel. The finding of reasons of using code switching appeared in the conversation as shows in table below.

Table 5.2. Reasons of Code Switching

\begin{tabular}{|l|l|l|}
\hline $\begin{array}{l}\text { Reasons of using Code Switching } \\
\text { in For Nadira }\end{array}$ & Frequency & Percentage \\
\hline Asserting power, pride \& status & 4 & $6 \%$ \\
\hline Declaring solidarity & 9 & $13 \%$ \\
\hline Expressing ethnic identity & 3 & $5 \%$ \\
\hline Expressing self emotion & 16 & $24 \%$ \\
\hline Being more competence & 3 & $5 \%$ \\
\hline Being more informative & 23 & $34 \%$ \\
\hline $\begin{array}{l}\text { Conveying the speaker's attitude to the } \\
\text { listener }\end{array}$ & 9 & $13 \%$ \\
\hline Total & $\mathbf{6 7}$ & $\mathbf{1 0 0 \%}$ \\
\hline
\end{tabular}

The previous explanation is to answer research question in this analysis. It is hoped that the present study has increased knowledge on code switching in the society and has helped us understand what code switching is and why it comes into being.

\section{References}

Aitchison, J. 2003. Linguistics. London: Hodder \& Stoughton Ltd.

Ayeomoni. 2006. "Code switching and Code Mixing: Style of Language Use in Childhood in Yoruba Speech Community". Nordic journal of African Studies 15(1): 90-99. 
Chaer, Abdul and Agustina, Leoni. 2004. Sosiolinguistik: Perkenalan Awal. Jakarta: Rineka Cipta.

Hoffman, Charlotte. 1991. An Introduction to Bilingualism. Inc: Longman.

Holmes, Janet. 1992. An Introduction to Sociolinguistics. Inc: Longman.

Romaine, Suzane. 1994. Language in Society: An Introduction to Sociolinguistics. Oxford: Oxford University Press.

Salikha Chudori, Leila. 2015. For Nadira. Jakarta: (KPG) Keperpustakaan Populer Gramedia.

Sankoff, D., \& Poplack, S. 1981. A formal grammar for code-switching. Papers in Linguistics, 14(1), 3-45.

Sankoff, D., \& Poplack, S. 1984. Borrowing: The Synchrony of Integration: Linguistics 22, 99135.

Wardaugh, Ronald. 1998. Introduction to Sociolinguistics, 3rd edition. Blackwell Publisher.

Wardaugh, Ronald. 2006. Introduction to Sociolinguistics, 5th edition. Blackwell Publisher. 